\title{
Contextual Effect of "Posyandu" in the Incidence of Anemia in Children under Five
}

\author{
Rokhayati1), Harsono Salimo'), Bhisma Murti1) \\ 1)Masters Program in Public Health, Universitas Sebelas Maret \\ ${ }^{2)}$ Department of Pediatrics, Dr. Moewardi Hospital, Surakarta
}

\begin{abstract}
Background: Iron deficiency can cause anemia which adversely affects children's growth, especially in terms of achievement, quality of life, and performance as human resources in the future. Birth weight, exclusive breastfeeding complementary feeding (EBF-CF) have a direct relationship with the incidence of anemia in infants. The purpose of this study is to examine the factors that influence anemia in children under five at the Banguntapan II Bantul Health Center, Yogyakarta.
\end{abstract}

Subjects and Method: The cross sectional study was conducted at 25 posyandu in the working area of Banguntapan II Bantul Health Center, Yogyakarta, Indonesia. A sample of 200 children aged 24-60 months was selected by simple random sampling. The dependent variable is anemia in infants. Independent variables are exclusive breastfeeding, breastfeeding, birth weight, nutritional status (BB / TB), mother's education, and mother's work. Anemia data was measured by Hb meter, other variable data were collected using questionnaires. The data were analyzed using a multiple logistic regression with a multilevel approach.

Results: The risk of anemia in infants is reduced by exclusive breastfeeding $(\mathrm{b}=-5.77 ; 95 \% \mathrm{CI}=-$ 11.30 to $-0.24 ; \mathrm{p}=0.041)$, EBF-CF administration is appropriate $(\mathrm{b}=-12.24 ; 95 \% \mathrm{CI}=-22.47$ to 2.00 , $\mathrm{p}=0.019)$, birth weight $2500-4000 \mathrm{~g}(\mathrm{~b}=-5.04$; CI $95 \%=-9.87$ to $0.21 ; \mathrm{p}=0.040)$, good nutritional status $(-2 \mathrm{SD}-+2 \mathrm{SD})(\mathrm{b}=-9.11$; CI $95 \%=-17.99$ to $0.23 ; \mathrm{p}=0.044)$, high maternal education (high school) ( $\mathrm{b}=-10.96 ; 95 \% \mathrm{CI}=-20.61$ to $1.31 ; \mathrm{p}=0.026$ ), and mothers who work at home $(\mathrm{b}=-5.98 ; 95 \% \mathrm{CI}=-11.27$ to $-0.68 ; \mathrm{p}=0.026)$. Posyandu strata showed that there was a contextual influence of posyandu on variations in anemia incidence (ICC $=62.62 \%)$.

Conclusions: Exclusive breastfeeding, proper EBF-CF, normal birth weight, good nutritional status, high maternal education, and mothers working at home reduce the risk of anemia in infants.

Keywords: anemia, children under five, exclusive breastfeeding, multilevel

\section{Correspondence:}

Rokhayati. Public Health Master's Program, Universitas Sebelas Maret, Surakarta, Jl. Ir. Sutami No. 36 A, 57126, Surakarta, Jawa Tengah.Email: ocharochayati1991@gmail.com. Mobile +6285328014414

\section{BACKGROUND}

The growth period of the children under five age (o-5 years) is also called the golden age, mainly because of rapid brain growth. Experts classify the age of children as a developmental stage of children who are quite vulnerable to various diseases, including diseases caused by excess or lack of certain types of nutritional intake (Teixeira et al., 2010). Malnutrition (mal- nutrition, micronutrient deficiencies, and being overweight / obese) over a 0-5 year period can increase morbidity and mortality risk. Malnutrition is estimated to cause $45 \%$ of deaths of children under five years, which is 3.1 million child deaths worldwide each year. In the long run, malnutrition during the first 1000 days of life can have an impact on adult health (Duan et al., 2013). In 2012, Household Health Survey (SKRT) 
reported that the prevalence of anemia in children under five in Indonesia reached 40.5\% (Ministry of Health, 2013).

Anemia is a decrease in blood hemoglobin concentration which is one of the most common nutritional deficiency diseases he dies globally. This is a major public health problem that affects the entire age of the population with the highest prevalence among children under five years of age and pregnant women (Alene, 2014).

Micronutrient deficiencies, especially iron, have a direct impact on children's nutritional status and are the most common cause of anemia. This is a concern that the deficiency of hematopoietic micronutrients not only results in anemia, but also leads to various other things, such as the adverse effects of cognitive function (Ray et al., 2016).

Low birth weight is an important indicator of children's health status associated with infant mortality, this is a major health problem, especially in developing countries. Pregnant women with anemia are predisposing factors for low birth weight that trigger anemia in children (Elhassan, 2010). Maternal nutrition before and during pregnancy causes is $>50 \%$ of cases of low birth weight in developing countries (Oladeinde, 2015).

Breast milk is the first and main food that is optimal for babies. Although iron concentrations in breast milk are relatively low, the bioavailability is high. However, with the growth of the baby and increasing tissue requirements and for circulation, iron-rich complementary foods are needed at the right time (Fabrizio, 2014).

Proper administration of EBF-CF makes children vulnerable to anemia (Zuffo et al., 2016). Early recognition of complementary foods at the age of 3-6 months was significantly associated with a higher risk of anemia compared to those given supple- mentary foods from the age of 6 months (Fabrizio et al., 2014). Childhood is a factor associated with anemia, this is related to inaccuracy during the weaning process, exclusive breastfeeding for more than 6 months and supplementary feeding of dilute breast milk (Ewusie et al. 2014).

Lack of iron intake in children will have a bad impact on the health, growth and development of children. In fact, the slow pace of cognitive development and behavior of children due to iron deficiency can persist so that it can disrupt growth and development with a long-term effect (Zainel, 2018).

A children under five park is held in an effort to rehabilitate malnourished and protein sufferers to train mothers and those responsible for managing children under five in family parks, how to take care of and cook and provide nutritious food for children under five, supplementary feeding programs (PMT) and Corrective Efforts Family Nutrition (UPGK) (Burkeet et al., 2018).

The government also held a children under five weighing program at the posyandu. Follow-up from the results of weighing in addition to counseling are providing additional food and providing nutritional supplements (Ministry of Health, 2013).

The success of the Posyandu program can be seen from the quality of its services, namely children under five weighing, counseling, and supplementary feeding activities that influence the nutritional status of children. Cadre participation in the posyandu is very high, thus affecting the success of supplementary feeding counseling (Khomsan et al., 2014).

Based on this, authors are interested in conducting study on the contextual effects of "posyandu" in the event of anemia in children under five in Yogyakarta. 


\section{SUBJECTS AND METHOD}

\section{Study Design}

This was a cross sectional study conducted in 25 posyandu in the working area of Banguntapan II Bantul Health Center, Yogyakarta, from March to April 2019.

\section{Population and Samples}

The population was all children under five aged 24-60 months in Bantul, Yogyakarta. Samples from 200 children were chosen by simple random sampling.

\section{Study Variables}

The dependent variable was the incidence of anemia in infants. Independent variables are exclusive breastfeeding, EBF-CF, birth rates, nutritional status, maternal education and maternal employment.

\section{Operational Definition of Vari- ables}

Exclusive breastfeeding was defined as giving breast milk to babies from birth for 6 (six) months, without adding and / or replacing with other foods or drinks. The measurement scale was continuous and converted into a dichotomy, code o for exclusive breastfeeding and 1 for those who are not exclusively breastfed.

EBF-CF was defined as additional food since a 6-month-old baby was in accordance with the texture, frequency and amount. The measurement scale was continuous and converted into a dichotomy, code $\mathrm{o}$ for EBF-CF was not correct and 1 for $\mathrm{EBF}-\mathrm{CF}$ is correct.

Birth weight was defined as the baby's weight at birth. The measurement scale was continuous and was converted into a dichotomy. Code o for birth weight $<2500$ or $>4000$ and 1 for birth weight 2500g4000 .

Nutritional status (BB / TB) was defined as a minimum measurement in children to assess growth and nutritional status. The measurement scale was continuous and was converted into a dichotomy. Code o for indexes $<2 \mathrm{SD}$ and $>+2 \mathrm{SD}$ and 1 for indexes $-2 \mathrm{SD}-+2 \mathrm{SD}$.

Mother's education was defined as a conscious and planned effort to realize the learning atmosphere of students to get the skills needed by themselves, society, nation and country. The categorical measurement scale was converted into a dichotomy. Code o was for elementary-junior high school education and 1 for high school and PT.

Mother's occupation was defined as a human endeavor so that it gets a reward or reward to develop the potential or ability that exists in him with the aim of fulfilling the necessities of life. The categorical measurement scale is converted into a dichotomy. Code o was for mothers who work outside the home and 1 was for mothers who work at home.

\section{Data Analysis}

Univariate analysis was conducted to examine the frequency distribution and characteristics of the study subjects. Bivariate analysis was performed using Chi-square and the 95\% Odds Ratio (CI) calculation to study the relationship between anemia and independent variables. Multivariate analysis was performed using logistic regression through a multilevel approach as indicated by the value of Intra Class Correlation (ICC).

\section{Research Ethics}

Researches ethics include inform consent, anonymity, confidentiality, and ethical permits. The research ethics was obtained from the Health Research Ethics Commission of the Faculty of Medicine UNS, Surakarta, Central Java based on the decision number: 450 / UN27.06 / KEPK / 2019.

\section{RESULTS}

\section{Univariate Analysis}

Table 1 showed the average age of children under five aged 3.85 years, with the youngest age of 3 years and the oldest at 5 
years. The average birth weight is $2.96 \mathrm{~kg}$, with the lowest weight of $1.7 \mathrm{~kg}$ and the highest of $4.4 \mathrm{~kg}$.

The average body weight when taking data is $13.77 \mathrm{~kg}$, with the lowest body weight of $8.2 \mathrm{~kg}$ and the highest body weight of $19 \mathrm{~kg}$. The average height is 95.46 $\mathrm{cm}$, with a minimum height of $80 \mathrm{~cm}$ and the highest $112 \mathrm{~cm}$. Hb levels averaged $12.22 \mathrm{mg} / \mathrm{dL}$ with a minimum value of 8.9 $\mathrm{mg} / \mathrm{dL}$ and the highest value was $14.3 \mathrm{mg}$ / dL.

Table 1. Univariate analysis of continuous data

\begin{tabular}{llllll}
\hline Variables & Obs & Mean & SD & Min & Max \\
\hline Children under five age (year) & 200 & 3.85 & 0.79 & 3 & 5 \\
Birth Weight (kg) & 200 & 2.96 & 0.48 & 1.7 & 4.4 \\
Weight (kg) & 200 & 13.77 & 1.96 & 8.2 & 19 \\
Height (cm) & 200 & 95.46 & 6.52 & 80 & 112 \\
Hb level (mg/dL) & 200 & 12.22 & 1.08 & 8.9 & 14.3 \\
\hline
\end{tabular}

Table 2 showed the majority of exclusive breastfeeding, proper EBF-CF administration, normal birth weight, good nutritional status, high maternal education, mothers working at home and children under five who do not have anemia.

Table 2. Univariate analysis of categorical data

\begin{tabular}{llcc}
\hline & Variable & N & \% \\
\hline Exclusive breastfeeding & Yes & 158 & $79 \%$ \\
EBF-CF & No & 42 & $21 \%$ \\
& Proper EBF-CF & 176 & $88 \%$ \\
Birth Weight & Not proper EBF-CF & 24 & $12 \%$ \\
& $2500-4000$ g & 164 & $82 \%$ \\
Nutritional Status (weight/height) & $<2500$ and > 400og & 36 & $18 \%$ \\
& -2 SD - +2SD & 144 & $75 \%$ \\
Maternal education & $<-2 S D$ and >+2 SD & 56 & $28 \%$ \\
& PS-JHS & 153 & $76.5 \%$ \\
Maternal occupation & SHS-College & 47 & $23.5 \%$ \\
& Working at home & 140 & $70 \%$ \\
Anemia & Working outside & 60 & $30 \%$ \\
& Anemia & 20 & $(90 \%)$ \\
& Not Anemia & 180 & $(10 \%)$ \\
\hline
\end{tabular}

\section{Bivariate Analysis}

Bivariate analysis was performed to investigate the relationship of independent variables (exclusive breastfeeding, birth weight, nutritional status, maternal education and maternal work) with the dependent variable (anemia). 
Rokhayati et al./ Contextual Effect of "Posyandu" in the Incidence of Anemia in Children

Table 2 Bivariate analysis

\begin{tabular}{|c|c|c|c|c|c|c|c|}
\hline \multirow{3}{*}{ Variable } & \multicolumn{4}{|c|}{ Anemia } & \multirow{3}{*}{ Total } & \multirow{3}{*}{ OR } & \multirow{3}{*}{$\mathbf{p}$} \\
\hline & \multicolumn{2}{|c|}{ Anemia } & \multicolumn{2}{|c|}{ Not anemia } & & & \\
\hline & $\mathbf{n}$ & $\%$ & $\mathbf{n}$ & $\%$ & & & \\
\hline \multirow{2}{*}{\multicolumn{8}{|c|}{$\begin{array}{l}\text { Exclusive } \\
\text { Breastfeeding }\end{array}$}} \\
\hline & & & & & & \multirow{3}{*}{9.67} & \\
\hline No & 7 & $4.4 \%$ & 151 & $95.6 \%$ & 158 & & \multirow[t]{2}{*}{$<0.001$} \\
\hline Ye & 13 & $31.0 \%$ & 29 & $69.0 \%$ & 42 & & \\
\hline \multicolumn{8}{|l|}{ EBF-CF } \\
\hline Proper & 5 & $2.8 \%$ & 171 & $97.2 \%$ & 176 & \multirow[t]{2}{*}{0.01} & \multirow[t]{2}{*}{$<0.001$} \\
\hline Not proper & 9 & $37.5 \%$ & 15 & $62.5 \%$ & 24 & & \\
\hline \multicolumn{8}{|l|}{ Birth Weight } \\
\hline $2500-4000 \mathrm{~g}$ & 5 & $3.0 \%$ & 159 & $97.0 \%$ & 164 & \multirow[t]{3}{*}{0.05} & \multirow[t]{3}{*}{$<0.001$} \\
\hline$<2500$ and $>4000 \mathrm{~g}$ & 15 & $41.7 \%$ & 21 & $58.3 \%$ & 36 & & \\
\hline \multicolumn{6}{|l|}{$\begin{array}{l}\text { Nutritional Status } \\
\text { (weight/height) }\end{array}$} & & \\
\hline$-2 \mathrm{SD}-+2 \mathrm{SD}$ & 4 & $2.8 \%$ & 140 & $97.2 \%$ & 144 & \multirow[t]{3}{*}{0.07} & \multirow[t]{3}{*}{$<0.001$} \\
\hline$<-2 \mathrm{SD}$ and $>+2 \mathrm{SD}$ & 16 & $28.6 \%$ & 40 & $71.4 \%$ & 56 & & \\
\hline \multicolumn{6}{|l|}{ Maternal education } & & \\
\hline SHS-College & 4 & $2.6 \%$ & 149 & $97.4 \%$ & 153 & \multirow[t]{3}{*}{0.05} & \multirow[t]{2}{*}{$<0.001$} \\
\hline PS-JHS & 16 & $28.6 \%$ & 40 & $66.0 \%$ & 47 & & \\
\hline \multicolumn{7}{|l|}{ Maternal Occupation } & \\
\hline At home & 7 & $5 \%$ & 134 & $95 \%$ & 141 & 0.18 & $<0.001$ \\
\hline Outside of house & 13 & $22.0 \%$ & 46 & $78.0 \%$ & 59 & & \\
\hline
\end{tabular}

Table 2 showed that infants who were given exclusive breastfeeding ( $\mathrm{OR}=9.67 ; 95 \%$ $\mathrm{CI}=3.55$ to $26.31 ; \mathrm{p}<0.001)$, EBF-CF $(\mathrm{OR}=$ $0.01 ; 95 \% \mathrm{CI}=0.06$ to $0.01 ; \mathrm{p}<0.001)$, birth weight $(\mathrm{OR}=0.05 ; 95 \% \mathrm{CI}=0.02$ to $0.13 ; \mathrm{p}<0.001$ ), good nutritional status (BB / TB) $(\mathrm{OR}=0.07 ; 95 \% \mathrm{CI}=0.02$ to $0.22 ; \mathrm{p}$ $<0.001)$, maternal education high (OR = $0.05 ; 95 \% \mathrm{CI}=0.02$ to $0.17 ; \mathrm{p}<0.001)$, and mothers working at home $(\mathrm{OR}=0.18 ; 95 \%$ $\mathrm{CI}=0.07$ to $0.49 ; \mathrm{p}<0.001$ ).

\section{Multivariate Analysis}

Multiple logistic regression analysis was performed using multilevel approach to explain the influence of more than one independent variable (exclusive breastfeed- ing, breastfeeding, birth weight, nutritional status (BB / TB), maternal education and maternal work) on the dependent variable (anemia).

Table 3 shows exclusive breastfeeding, breastfeeding, birth weight, nutritional status, education, and employment have a statistically significant influence on the incidence of anemia. Data analysis at the posyandu level showed an ICC score of $62.62 \%$, this indicates that variations in anemia of $62.62 \%$ are determined by the variable level of the posyandu. The ICC score in this study is greater than 8-10\%, so the contextual influences which are posyandu are very important.

Table 3 Multilevel multiple logistic analysis

\begin{tabular}{|c|c|c|c|c|}
\hline \multirow[b]{2}{*}{ Independent Variable } & \multirow[b]{2}{*}{$\mathbf{b}$} & \multicolumn{2}{|c|}{ CI 95\% } & \multirow[b]{2}{*}{$\mathbf{p}$} \\
\hline & & $\begin{array}{c}\text { Lower } \\
\text { Limit }\end{array}$ & $\begin{array}{l}\text { Upper } \\
\text { Limit }\end{array}$ & \\
\hline \multicolumn{5}{|l|}{ Fixed-Effect } \\
\hline Exclusive breastfeeding & -5.77 & -11.30 & -0.24 & $<0.041$ \\
\hline EBF-CF (yes) & -12.24 & -22.47 & -2.00 & $<0.019$ \\
\hline Birth weight (normal) & -5.04 & -9.87 & -0.21 & $<0.040$ \\
\hline
\end{tabular}


Journal of Maternal and Child Health (2019), 4(6): 1-10

https://doi.org/10.26911/thejmch.2019.04.06.01

\begin{tabular}{|c|c|c|c|c|}
\hline Nutritional Status (good) & -9.11 & -17.99 & -0.23 & $<0.044$ \\
\hline Maternal education (high) & -10.96 & -20.61 & -1.31 & $<0.026$ \\
\hline Maternal mother (working at & -5.98 & -11.27 & -0.68 & $<0.027$ \\
\hline $\begin{array}{l}\text { home) } \\
\text { Variation (constant) }\end{array}$ & 18.41 & 2.22 & 34.60 & \\
\hline $\begin{array}{l}\text { Variation (constant) } \\
\text { Variation (cons) strata posyandu }\end{array}$ & & & & \\
\hline Random-Effect & $5 \cdot 51$ & 0.25 & 112.34 & \\
\hline $\mathrm{N}$ observation & 200 & & & \\
\hline $\mathrm{N}$ group & 4 & & & \\
\hline Average of the group & 50 & & & \\
\hline Min & 48 & & & \\
\hline $\operatorname{Max}$ & 52 & & & \\
\hline Log likehood & -10.87 & & & \\
\hline LR test vs. logistic regression (p) & 0.048 & & & \\
\hline ICC & $62.62 \%$ & & & \\
\hline
\end{tabular}

\section{DISCUSSION \\ 1. The effect of exclusive breast- feeding on the incidence of anemia}

The results showed that exclusive breastfeeding had a significant effect on the incidence of anemia in infants $(b=-5.77 ; 95 \%$ $\mathrm{CI}=-11.30$ to $-0.24 ; \mathrm{p}=0.041)$. Children under five who get exclusive breastfeeding are less likely to develop anemia by -5.77 compared to children under five who don't get exclusive breastfeeding.

This study was in line with the study (Ayuningrum et al., 2017), which states that there is a positive, direct and almost statistically significant effect of exclusive breastfeeding on the nutritional status of children under five. Study (Torres et al., 2006) states that exclusive breastfeeding until the sixth month of life inhibits the incidence of iron deficiency anemia.

Neervoort et al. (2012) stated that breastfeeding exclusively for 6 months and continued for up to 2 years could protect children from the risk of child illness and death, protection of child diseases that are common throughout the world until children aged 2 even more years.

\section{The Effect of breast milk on the incidence of anemia}

The results of this study indicate that EBF$\mathrm{CF}$ has a significant effect on the incidence of anemia in infants $(\mathrm{b}=-12.24 ; 95 \% \mathrm{CI}=-$ 22.47 to -2.00, $\mathrm{p}=0.019)$. Children under five who get EBF-CF have a lower chance of developing anemia by -12.24 compared to children under five who don't get EBF-CF properly.

Inadequate practice of administering EBF-CF was an important risk factor for available iron-deficiency anemia or iron absorption inhibitor foods. This kind of practice often prolongs iron-deficiency anemia up to the age of 2 years (Zainel et al., 2018).

\section{The Effect of Birth Weight on the incidence of anemia}

The results of this study indicate that birth weight has a significant effect on the incidence of anemia in infants $(b=-5.04 ; 95 \%$ $\mathrm{CI}=-9.87$ to $0.21 ; \mathrm{p}=0.040)$. Children under five born with normal weight (2500 to $4000 \mathrm{~g}$ ) are less likely to develop anemia as much as -5.04 compared with those born with a body weight $<2500 \mathrm{~g}$ and $>4000 \mathrm{~g}$.

The results of this study was in line with the study of Martin et al. (2018), which revealed that low body weight was a risk factor for anemia in children.

\section{The Effect of Nutritional Status on the incidence of anemia}

The results of this study indicate that the nutritional status of children has a significant influence on the incidence of 
anemia in infants $(b=-9.11 ; 95 \% \mathrm{CI}=-$ 17.99 to $0.23 ; \mathrm{p}=0.044)$. Children under five who have good nutritional status (BB / TB) are less likely to develop anemia as much as -9.11 compared to children under five who have nutritional status $<-2 \mathrm{SD}$ and $>+2 \mathrm{SD}$.

The results of this study are in line with the study of Martin et al. (2018) in their study saying that children with Iron Deficiency Anemia (IDA) significantly increase their weight slower, this is characterized by thinner and significantly slower growth rates and children shorter kids.

\section{The Effects of Mother's Education on the incidence of anemia}

The results of this study indicate that maternal education has a significant influence on the incidence of anemia in infants $(b=-$ 10.96; $95 \% \mathrm{CI}=-20.61$ to $1.31 ; \mathrm{p}=0.026$ ). Children under five who have mothers with high education are less likely to develop anemia as much as -10.96 compared to children under five from mothers with low education.

Education for girls, especially mothers, has been shown to have a direct relationship with improving their children's nutrition, and the indirect impact of reducing child mortality even controls household income (Saleh et al., 2017). This was supported by Lestari's study (2019), which states that there is an influence of education of mothers with exclusive breastfeeding, highly educated mothers have logout to give exclusive breastfeeding 2.10 units higher than those with low education, where with exclusive breastfeeding the child nutrition will increase so that the incidence of anemia in infants will decrease.

The study of Anggraini et al. (2017), showed that there was an indirect and statistically significant positive effect between maternal education and the incidence of anemia in infants. The influence of maternal education and anemia was also expressed by Abubakar et al. (2012), which states that the direct influence of maternal education was childcare practices, because mothers with higher education have been observed to provide optimal care for their children, girls' education / mother as a way to improve child welfare in developing countries.

\section{The Effect of Mother's Occupation on Anemia}

The results of this study indicate that the work of mothers has a significant influence on the incidence of anemia in infants $(b=-$ $5.98 ; 95 \% \mathrm{CI}=-11.27$ to $-0.68 ; \mathrm{p}=0.026$ ). Children under five who have mothers working at home are less likely to develop anemia as much as -5.98 compared to children under five whose mothers work outside the house.

According to Torres et al. (2014), housewives who do not work outside the home automatically have more time to care for and care for children. Mothers who work outside the home will increase their social value, but at the same time mothers who work result in a decrease in children's health.

Women's occupation was a conservation resource available to families, but on the other hand it can have a negative impact on the allocation of time or energy to care for children and is a major barrier in the practice of child feeding even though mothers have knowledge of proper feeding practices (Vir, 2016).

\section{The Effect of Posyandu on the incidence of anemia}

The results showed that there was a contextual influence of posyandu on variations in the incidence of anemia in infants (ICC = $62.62 \%)$. Variations in anemia incidence were $62.62 \%$ influenced by the strata of the posyandu. The ICC value in this study is 
greater than the benchmark 8-10\% rule of thumb, so the contextual influence that was in this study is very important to note.

Sinta et al. (2017) study showed that there was an influence of posyandu on exclusive breastfeeding $(\mathrm{ICC}=28.87 \%)$ which means that each level of posyandu has a contextual influence on exclusive breastfeeding of $28.87 \%$. Posyandu was considered as the most important mechanism for improving children under five nutrition and reducing infant mortality (Yousafzai et al., 2016).

The success of the Posyandu program can be seen from the quality of its services, one of which is the weighing of children under five, counseling, and supplementary feeding that affect the nutritional status of children. Cadre participation in posyandu is very high, thus affecting the success of supplementary feeding counseling (Merita et al., 2014).

\section{AUTHORS CONTRIBUTION}

Rokhayati as the main author in this study plays a role in determining the theme and title of the study, determining the location and study problems that occur in the community. Harsono Salimo has a role in providing the theoretical basis of this study problem. Bhisma Murti has a role in providing additional journal literacy in accordance with this study.

\section{FUNDING AND SPONSORSHIP}

This study used the authors' independent costs.

\section{CONFLICT OF INTEREST}

There IS no conflict of interest in this study.

\section{ACKNOWLEDGMENT}

The authors would like to express gratitude to the officers of the puskesmas, cadres, mothers of children under five who were participated in this study and also the Bantul Bappeda and the Bantul Health Office who gave permission for this study.

\section{REFERENCE}

Abubakar A, Uriyo J, Msuya SE, Swai M (2012). Prevalence and risk factors for poor nutritional status among children in the Kilimanjaro Region of Tanzania. 3506-3518. https://doi.org/10.3390/ijerph9103506

Alene KA, Dohe AM (2014). Prevalence of anemia and associated factors among pregnant women in an urban area of Eastern Ethiopia. 2014 (May 2013). https://doi.org/10.1155/2014/561567

Anggraini Y, Salimo H, Tamtomo D (2017). Effect of birthweight, illness history, and dietary pattern, on the incidence of anemia in children under-five at Tasikmadu Health Center, Karanganyar, Central Java. 2(3):200-212.https://doi.org/10.26911/thejmch.2017.02.01.04

Ayuningrum IY, Salimo H, Dewi YLR (2017). Path analysis on gestational socio-economic determinants of nutritional status in children under five in Purworejo Regency, Central Java. 2(1):30-41. Retrieved from https://doi.org/10.26911/thejmch.2017.02.0 1.04

Burkeet RM, Rebolledo PA, Aceituno AM, Revollo R, Iñiguez V, Klein M, Suchdev PS (2018). Effect of infant feeding practices on iron status in a cohort study of Bolivian infants. 1-9. Retrieved from https://dx.doi.org/10.1186\%2Fs12887-018-1066-2

Duan Y, Yang Z, Lai J, Yu D, Chang S, Pang $X$ (2013). Exclusive breastfeeding rate and complementary feeding indicators in china: A National Representative 
Survey in 2013. 1-9. https://doi.org/10.3390/nu10020249

Elhassan EM, Abbaker AO, Haggaz AD, Abubaker MS, Adam I (2010). Anemia and low birth weight in Medani, Hospital Sudan. BMC Research Notes, 3: o-4. https://doi.org/10.1186/17560500-3-181

Ewusie JE, Ahiadeke C, Beyene J, Hamid JS (2014). Prevalence of anemia among under-5 children in the Ghanaian population: estimates from the Ghana demographic and health survey. 14(1): 1-9. https://doi.org/10.1186/1471-2458-14-626

Fabrizio CS, Liere M, Van, Pelto G (2014). Original Article Identifying determinants of effective complementary feeding behaviour change interventions in developing countries. Maternal and Child Nutrition, (June 2013), 1-18. https://doi.org/10.1111/mcn.12119

Khomsan, Merita, Faisal DS (2014). Impact of nutritional education on service quality in the integrated service posts ( Posyandu). https://doi.org/10.3923/pjn.2014.122.128

Lestari E, Pamungkasari EP, Dewi Y LR (2019). Multilevel analysis on the contextual effect of posyandu on exclusive breastfeeding in Sleman, Yogyakarta. Journal of Maternal and Child Health, 4(4): 242-249. https://doi.org/https://doi.org-

/10.26911/thejmch.2019.04.04.04

Martin H, Kimanya ME, Mosha TCE (2018). Prevalence and predictors of anemia among children under 5 years of age in Arusha. Pediatric Health, Medicine and Therapeutics, 9-15. Retrieved from https://doi.org/10.2147/PHMT.S148515

Neervoort F, Rosenstiel I, Von, Bongers K, Demetriades M, Shacola M, Wolffers I (2012). Effect of a school feeding pro- gramme on nutritional status and anaemia in an Urban Slum: A Preliminary Evaluation in Kenya Effect of a School Feeding Programme on Nutritional Status and Anaemia in an Urban Slum: A Preliminary Evaluation in Kenya. (December). https://doi.org/10.1093/tropej/fmso7o

Oladeinde HB, Oladeinde OB, Omoregie R, Onifade AA (2015). Prevalence and determinants of low birth weight: The situation in a traditional birth home in Benin city, Nigeria. African Health Sciences, 15(4): 1123-1129. https://doi.org/10.4314/ahs.v15i4.10

Ray S, Chandra J, Bhattacharjee J, Sharma S, Agarwala A (2016). Determinants of nutritional anaemia in children less than five years age. 3(2): 403-408.

Kemenkes, RI (2013). Laporan akuntabiltas kinerja Kementerian Kesehatan RI.

Saleh A, Nurachmah E, Hadju V, As, S, Hamid SK (2017). Baby nutritional status improvement through mother empowerment in baby care in South Sulawesi Indonesia. Pakistan Journal of Nutrition, 16(1): 9-15. https://doi.org/10.3923/pjn.2017.9.15

Sinta P, Salimo H, Pamungkasari EP (2017). Multilevel analysis on the biosocial and economic determinants of exclusive breastfeeding. 2(4): 356370. https://doi.org/10.26911/thejmch.2017.02.04.06

Teixeira MDLPD, Lira PIC, Coutinho SB, Eickmann SH, Lima MDC (2010). Influence of breastfeeding type and maternal anemia on hemoglobin concentration in 6-month-old infants. 86(1): 65-72. https://doi.org/10.2223/JPED.1959

Torres MAA, Braga JAP, Taddei JAAC, Nóbrega FJ (2006). Anemia in lowincome exclusively breastfed infants. 284-288. https://doi.org/10.2223/JP- 
ED.1511

Vir SC (2016). Improving women 's nutrition imperative for rapid reduction of childhood stunting in South Asia: coupling of nutrition speci fi c interventions with nutrition sensitive measures essential. 12: 72-90. https://doi.org/10.1111/mcn.1225

Yousafzai AK, Obradović J, Rasheed MA, Rizvi A, Portilla XA, Tirado-Strayer N, Memon U, (2016). Effects of responsive stimulation and nutrition interventions on children's development and growth at age 4 years in a disadvantaged population in Pakistan: a longitudinal follow-up of a cluster-randomised factorial effectiveness trial.
The Lancet Global Health, 4(8): e548e558. https://doi.org/10.1016/S2214109X(16)30100-0.

Zainel AJAL, Osman SRO, Al-Kohji SMS, Selim NA (2018). Iron deficiency, its epidemiological features and feeding practices among infants aged 12 months in Qatar: A cross-sectional study. BMJ Open, 8(5):1-10. https://doi.org/10.1136/bmjopen-2017-020271

Zuffo CRK, Osório MM, Taconeli CA, Schmidt ST, Silva BHC, Almeida CCB (2016). Prevalência e fatores de risco da anemia em crianças. Jornal de Pediatria, 92(4): 353-360. https://doi.org/10.1016/j.jped.2015.09.007. 